\title{
Soil persistence of DNA from transgenic poplar
}

\author{
Martina BONADEI, Alma BALEStraZZI, Barbara FrIGerio and Daniela CARBONERA* \\ Dipartimento di Genetica e Microbiologia, Università di Pavia, via Ferrata 1, 27100 Pavia, Italy
}

The presence of recombinant DNA in soil cultivated with white poplars (Populus alba L.) expressing either the bar transgene for herbicide tolerance or the StSy transgene for resveratrol production, respectively, was investigated in a greenhouse over a 20-month period. The bar trial included the transgenic lines 5P56 and 6EA22P56 and the untransformed line, while the StSy trial was established with the transgenic lines 5EAC1 and 12EAC1 and with the untransformed line. All the transgenic poplars harbored the nptll marker gene. Plantlets were cultivated in pots, and soil samples were mixed in order to obtain composite pools which were used for molecular analyses. The 35SCaMV-bar (1504 bp), 35SCaMV-StSy (1403 bp) and NosP-nptll (1188 bp) sequences were detected in total DNA extracted from soil samples taken at different times after planting, using PCR/Southern blot hybridization. Microcosm experiments, carried out to assess the effects of temperature and DNA purity on transgene persistence, revealed only a partial correlation between the intensity of hybridization signals and the parameters tested.

Keywords: greenhouse trial / microcosm / Populus alba / recombinant DNA / soil persistence

\section{INTRODUCTION}

Recombinant DNA released by genetically modified (GM) plants in the soil environment could enhance the frequency of horizontal gene transfer (HGT) from plants to soil microorganisms, causing the undesired spread of transgenes (Monier et al., 2007; Pontiroli et al., 2007). In recent work, HGT events involving bulk and rhizosphere soil bacteria exposed to recombinant DNA were detected at extremely low frequency (Keese, 2008) while the absence of transformable bacteria in rhizosphere- and soilassociated communities suggests that natural transformation represents a rare event (Richter and Smalla, 2007; Van Overbeek et al., 2007).

To date, most of the studies concerning DNA persistence in soil have been carried out using GM annual plants (Pontiroli et al., 2007). Notwithstanding the fact that the exposure of soil-borne microorganisms to the GM material is also dependent on the life-span of the plant, information on forest tree species on this topic is still scanty. Hay et al. (2002) investigated the persistence of the nptII marker gene, conferring kanamycin resistance, in decomposing transgenic poplar leaves. The latter were placed in permeable bags and located in a field trial for up to 12 months under different environmental conditions. The recombinant DNA sequences were detected for less than four months. England et al. (2004) used forest litter microcosms spiked with the DNA from

*Corresponding author: carbo@ipvgen.unipv.it a GM baculovirus strain and demonstrated that the target sequence was present for up to three months.

Detection of recombinant DNA in soil microcosms seeded with ground leaf tissue might be affected by factors related to the leaf litter biochemistry which can exert direct effects on the metabolic activities of soil microbial communities and influence the rate of organic matter degradation (Hobbie et al., 2006). Furthermore, it has been reported that plant species with relatively low litter lignin exhibited rapid decomposition rates (Alhamd et al., 2004). The soil microbiological properties during decomposition of Populus deltoides leaf litter have been analyzed and compared with Eucalyptus tereticornis by Chander et al. (1995), who demonstrated that decomposition of eucalyptus leaves in soils was slower than that of poplar leaves. More recently, Cotrufo et al. (2005) investigated litter decomposition of three Populus spp. and observed responses that were strongly species-specific. A more detailed investigation on the dynamics of poplar leaf decomposition in soil focusing on the role of relevant factors still poorly explored, such as the residuesphere (Ceccherini et al., 2003), will help to better assess the fate of recombinant DNA in the soil environment.

The elite cultivar 'Villafranca' (Populus alba L.) used in the present study has become a model system in tree biotechnology, and transgenic plants have been produced using, not only conventional gene transfer techniques (Balestrazzi et al., 2006; Giorcelli et al., 2004; Zelasco et al., 2006), but also innovative vector systems for marker-free applications (Zelasco et al., 2007). 
The GM poplar lines 5P56 and 6EA22P56 (Confalonieri et al., 2000) used in this investigation carried a single copy of the bar gene from Streptomyces hygroscopicus (Thompson et al., 1987), conferring resistance to the herbicide Basta ${ }^{\circledR}$. The transgenic lines 5EAC1 and 12EAC1 (Giorcelli et al., 2004) carried a single copy of the StSy gene from Vitis vinifera (Sparvoli et al., 1994) encoding the stilbene synthase enzyme responsible for resveratrol production. Both the bar and StSy genes were placed under the control of the constitutive $35 \mathrm{SCaMV}$ promoter. The GM poplars carried also a single copy of the nptII marker gene under the control of the nopaline synthase gene promoter.

PCR and Southern blot hybridization techniques were used to detect the recombinant DNA in total DNA extracted directly from the soil of two experimental trials established with the bar and StSy GM poplars, respectively, under greenhouse conditions.

Finally, it is worth noting that information concerning the fate of recombinant DNA in soil can be acquired on different scales, and microcosms that mimic the conditions of agricultural soils have been used to monitor DNA persistence and degradation (Lilley et al., 2003; Pontiroli et al., 2007). In the present work, microcosm experiments were carried out with loamy sand in order to investigate the effect of DNA purity and temperature on the fate of the 35SCaMV-bar, 35SCaMV-StSy and NosP-nptII sequences.

\section{RESULTS}

\section{Presence of recombinant DNA in soil cultivated with GM white poplars}

The trials were planted in the greenhouse in March 2004, using plantlets produced by in vitro micropropagation. The experimental design and the sampling scheme of the bar and StSy trials are shown in Figure 1. Two independent replicates were collected per treatment and sampling point. Total DNA was extracted and the occurrence of the NosP-nptII, 35SCaMV-bar and 35SCaMV-StSy sequences was evaluated by PCR and Southern blot hybridization. For each DNA sample three replicates were used and three independent PCR assays were carried out. When the soil DNA samples were tested in PCR assays with universal bacterial oligonucleotides, the amplification of the $16 \mathrm{~S}$ rDNA sequence was always observed. The recombinant DNA sequences NosP-nptII (1188 bp) and 35SCaMV-bar (1504 bp) were detected using oligonucleotide primers which target both the promoter and the associated coding region, in order to avoid the undesired amplification of naturally occurring nptII and bar genes. The latter were detected in the same soil before GM poplar cultivation, using oligonucleotide primers specific for the nptII and bar coding region (data not shown).

As for the bar trial, samples were first collected in March 2004, in the absence of GM poplars, and molecular analyses performed on the nine pools failed to reveal the presence of the NosP-nptII and 35SCaMV-bar sequences in the soil environment (Tab. 1, bar, 0). After planting, when the average plant height was $30 \mathrm{~cm}$, new samples were taken. It is worth noting that for those soil pools positive to molecular analyses, amplicons were visible only after hybridization with the gene-specific probes. Furthermore, DNA from each pooled sample was amplified three times. Five out of the nine pools from the bar field were positive for the PCR/Southern blot hybridization specific for the NosP-nptII transgene, while eight out of the nine pools contained the 35SCaMVbar transgene (Tab. 1, bar, 3). At six months, the number of NosP-nptII positive pools was eight out of nine, while the number of pools carrying the 35SCaMV-bar sequence decreased slightly (7/9). Twelve and 18 months after planting (March and August 2005, respectively) the same number (8/9) of positive samples was recorded for both the target sequences.

As concerns the StSy trial, no amplification products corresponding to NosP-nptII (1188 bp) and 35SCaMVStSy (1403 bp) were detected before planting (Tab. 1, $S t S y, 0)$. Three months later, approximately eight pools out of twelve were positive in the NosP-nptII-specific assay, and six months after planting the number further increased to 10/12 (Tab. 1, StSy, 3 and 6). This value remained constant until the end of the experiment (Tab. 1, StSy, 6, 12 and 18). As concerns the 35SCaMV-StSy region, the number of positive pools was approximately $5 / 12$ and $6 / 12$, three and six months after planting (Tab. 1 , StSy, 3 and 6). However, 12 months after planting, the fraction of positive pools increased (10/12), and then remained constant until the end of the experiment (Tab. 1, StSy, 12 and 18).

The detection limit was assessed with PCR/Southern blot hybridization experiments in which purified poplar DNA extracted from the GM lines was used as template. The intensity of the hybridization signal produced by soil DNA was similar to that obtained using $0.005-0.02 \mathrm{ng}$ of purified poplar DNA as template. Since the poplar diploid genome size is estimated to be $1.12 \mathrm{pg}$, the detection limit of the system ranged within 5-20 copies of the target sequence.

\section{Persistence of recombinant DNA in soil microcosms}

Replicated microcosms carrying purified DNA and ground leaf tissue, respectively, were incubated at $4{ }^{\circ} \mathrm{C}$ and $28{ }^{\circ} \mathrm{C}$, for the indicated times. The soil samples 
A

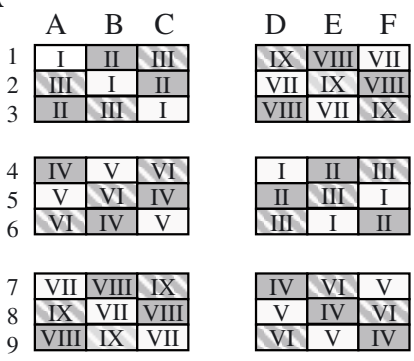

5P56 $\mathrm{CEA22P56} \mathrm{DCTRL}$
B

pool (line)

I (5P56)

II (6EA22P56)

III (CTRL)

IV (6EA22P5)

$\mathrm{V} \quad(5 \mathrm{P} 56)$

VI (CTRL)

VII (5P56)

VIII (6EA22P56)

IX (CTRL)
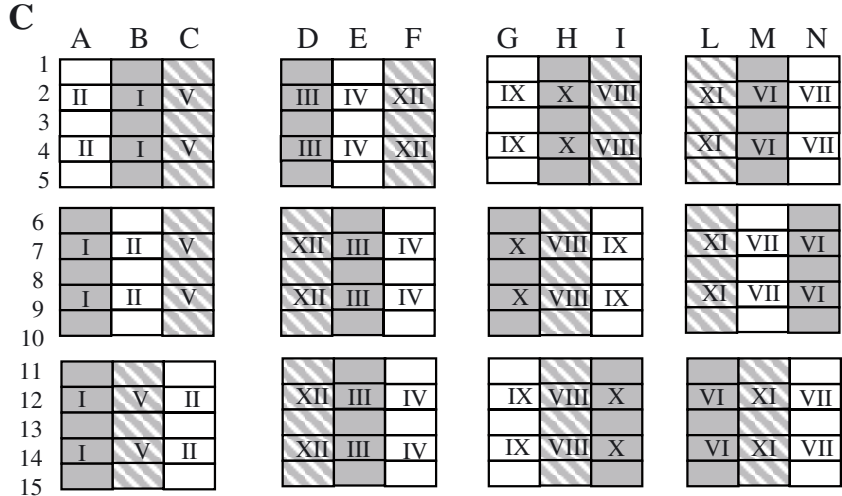

D

12EAC1 $\square$ 5EAC1 $\square$ CTRL

$\begin{array}{llclll}\text { pool } & \text { (line) } & \text { pool } & \text { (line) } & \text { pool } & \text { (line) } \\ \text { I } & (\text { 12EAC1) } & \text { V } & \text { (CTRL) } & \text { IX } & \text { (5EAC1) } \\ \text { II } & \text { (5EAC1) } & \text { VI } & \text { (12EAC1) } & \text { X } & \text { (12EAC1) } \\ \text { III } & \text { (12EAC1) } & \text { VII } & \text { (5EAC1) } & \text { XI } & \text { (CTRL) } \\ \text { IV } & \text { (5EAC1) } & \text { VIII } & \text { (CTRL) } & \text { XII } & \text { (CTRL) }\end{array}$

Figure 1. A. Schematic representation of the bar trial. Each box represents a single plant belonging to GM line 5P56 (white box), GM line 6EA22 (grey box) and to the untransformed CTRL line (white and gray box). Each plant has been associated with a number (from I to IX) corresponding to a specific soil pool. B. List of the nine soil pools obtained from the bar trial. Each pool, numbered from I to IX, contained soil collected from six pots cultivated with the same poplar line. C. Schematic representation of the StSy trial. Each box represents a single plant belonging to GM line 12EAC1 (white box), GM line 5EAC1 (grey box) and to the untransformed CTRL line (white and gray box). Each plant has been associated with a number (from I to XII) corresponding to a specific soil pool. Plants without numbers were not analyzed. D. List of the twelve soil pools obtained from the StSy trial. Each pool, numbered from I to XII, contained soil collected from six pots cultivated with the same poplar line.

contained either $0.5 \mathrm{~g}$ of ground poplar leaf tissue or $500 \mathrm{ng}$ of purified poplar genomic DNA. An average total DNA yield of 20-22.5 $\mu \mathrm{g}$ DNA was recovered from each gram of fresh soil, including the untreated soil samples. PCR assays were carried out using for each sample an equal volume $(5 \mu \mathrm{L})$ containing $5 \mathrm{ng}$ of total soil DNA. At the beginning of the experiment, the intensity of the hybridization signal produced by all the target sequences was in the range of 1.0-2.0 $\times 10^{6} \mathrm{cpm}$ (Fig. 2). As concerns the detection of the 35SCaMV-bar sequence in soil maintained at $4{ }^{\circ} \mathrm{C}$, variability was observed in the intensity of the hybridization signals obtained from microcosms seeded with purified DNA and ground tissues throughout the tested period, except for the last time point ( 10 weeks after the beginning of the experiment), when similar values $\left(0.7-0.9 \times 10^{6} \mathrm{cpm}\right)$ were recorded (Fig. 2A, 1). The microcosms containing ground tissue and incubated at $4{ }^{\circ} \mathrm{C}$ showed an increased intensity of the hybridization signal at three weeks $(1.7 \times$ $10^{6} \mathrm{cpm}$ ) (Fig. 2A, 1). At $28^{\circ} \mathrm{C}$, in both types of microcosms there was clearly a time-dependent decrease in the intensity of hybridization signals which ranged from $1.9-2.1 \times 10^{6}$ to $0.3-0.6 \times 10^{6} \mathrm{cpm}$ (Fig. 2B, 2).

When the 35SCaMV-StSy sequence was monitored at $4{ }^{\circ} \mathrm{C}$, opposite responses were observed at one week, as the hybridization signal decreased (from $1.5 \times 10^{6}$ 
Table 1. Oligonucleotide primer sets used to detect recombinant DNA in soil samples.

\begin{tabular}{|c|c|c|}
\hline Oligonucleotide & Sequence & $\begin{array}{l}\text { Amplicon } \\
\text { size (bp) }\end{array}$ \\
\hline Nos-1 & 5'-GAGCGGAGAATTAAGGGAGTCA-3' $^{\prime}$ & NosP-nptII \\
\hline $\mathrm{K}-3$ & $5^{\prime}$-GGCGATAGAAGGCGATGCGCTG-3' & 1188 \\
\hline 35S-FW1 & $5^{\prime}$-CAGAAAGAATGCTAACCCACAGA-3' & 35SCaMV-bar \\
\hline BAR-3 & 5'-CAGATCTCGGTGACGGGCAG-3' & 1504 \\
\hline 35S-FW2 & 5'-CAGTGGTCCCAAAGATGGACC-3' & 35SCaMV-StSy \\
\hline StSy-2 & 5'-TTAATTTGTCACCATAGGAATGCTA-3' & 1403 \\
\hline $\mathrm{K}-1$ & 5'-AGGCTAATTCGGCTATGACTGG-3' & nptII \\
\hline $\mathrm{K}-2$ & $5^{\prime}$-GCGGTCCGCCACACCCAGCCG-3' & 549 \\
\hline BAR-1 & $5^{\prime}$-TCCCCCGGGGGAATGAGCCCAGAACGACGCCC-3' & bar \\
\hline BAR-2 & 5'-CGAGCTCGTCAGATCTCTGTGACGGGCAG-3' & 652 \\
\hline StSy-1 & 5'-ATGGCTTCAGTCGAGGAAATTAG-3' & StSy \\
\hline StSy-2 & 5'-TTAATTTGTCACCATAGGAATGCTA-3' & 1178 \\
\hline
\end{tabular}

Table 2. Detection of recombinant DNA sequences in loamy sand cultivated with transgenic white poplars. PCR analyses were carried out using gene-specific oligonucleotide primers that allowed the amplification of DNA fragments spanning both the promoter and the coding region.

\begin{tabular}{ccccc}
\hline & \multicolumn{3}{c}{ Experimental trial } \\
\cline { 2 - 5 } & \multicolumn{2}{c}{ bar } & \multicolumn{3}{c}{ StSy } \\
\hline $\begin{array}{c}\text { Months after } \\
\text { planting }\end{array}$ & 35SCaMV-bar ${ }^{\mathrm{a}}$ & NosP-nptII & 35SCaMV-StSy & NosP-nptII \\
0 & & & & \\
3 & n.d. $^{\text {b }}$ & n.d. & n.d. & n.d. \\
6 & $8 / 9$ & $5 / 9$ & $5 / 12$ & $8 / 12$ \\
12 & $7 / 9$ & $8 / 9$ & $6 / 12$ & $6 / 12$ \\
18 & $8 / 9$ & $8 / 9$ & $6 / 12$ & $6 / 12$ \\
& $8 / 9$ & $8 / 9$ & $6 / 12$ & $6 / 12$ \\
\hline
\end{tabular}

${ }^{a} \mathrm{~N}^{\circ}$ positive pools $/ \mathrm{N}^{\circ}$ total pools; ${ }^{\mathrm{b}}$ not detected.

to $\left.1.0 \times 10^{6} \mathrm{cpm}\right)$ in microcosms seeded with purified DNA, and increased (from $0.9 \times 10^{6}$ to $1.5 \times 10^{6} \mathrm{cpm}$ ) in those samples containing ground leaf tissue (Fig. 2A, 3). When the microcosms were incubated at $28{ }^{\circ} \mathrm{C}$, no differences were observed in the intensity of hybridization between the two treatments (Fig. 2B, 4). In microcosms diluted with purified DNA and incubated at $4{ }^{\circ} \mathrm{C}$, the amount of the NosP-nptII PCR product showed an enhancement at one week (from $0.8 \times 10^{6}$ to $2.6 \times 10^{6} \mathrm{cpm}$ ), while in microcosms containing the ground tissue, a peak in the hybridization signal $\left(1.4 \times 10^{6} \mathrm{cpm}\right)$ was observed at three weeks. The detection patterns observed at $28{ }^{\circ} \mathrm{C}$ were quite similar for both types of microcosms, and ranged from $1.8-1.9 \times 10^{6} \mathrm{cpm}$ to $0.4-0.8 \times 10^{6} \mathrm{cpm}$ (Fig. 2B, 6).

The efficacy of the detection system was assessed by PCR/Southern hybridization experiments carried out using as template diluted amounts of purified poplar genomic DNA extracted from the 5P56 and 12EAC1 GM lines. The intensity of the NosP-nptII hybridization signal produced by PCR amplification of $0.02 \mathrm{ng}$ of purified poplar DNA was similar to the highest NosP-nptII hybridization signal obtained in Figure 2B (week 0, purified DNA). In this specific case, the system was highly effective (close to $100 \%$ ) in monitoring the recombinant DNA in soil, since the estimated amount of poplar DNA in each tube corresponded to $0.027-0.031 \mathrm{ng}$. The efficacy was reduced in other cases.

\section{DISCUSSION}

The investigation carried out with the bar and StSy trials showed that detectable amounts of the recombinant DNA were present in the soil. The increasing proportion of the total root system that developed in each 


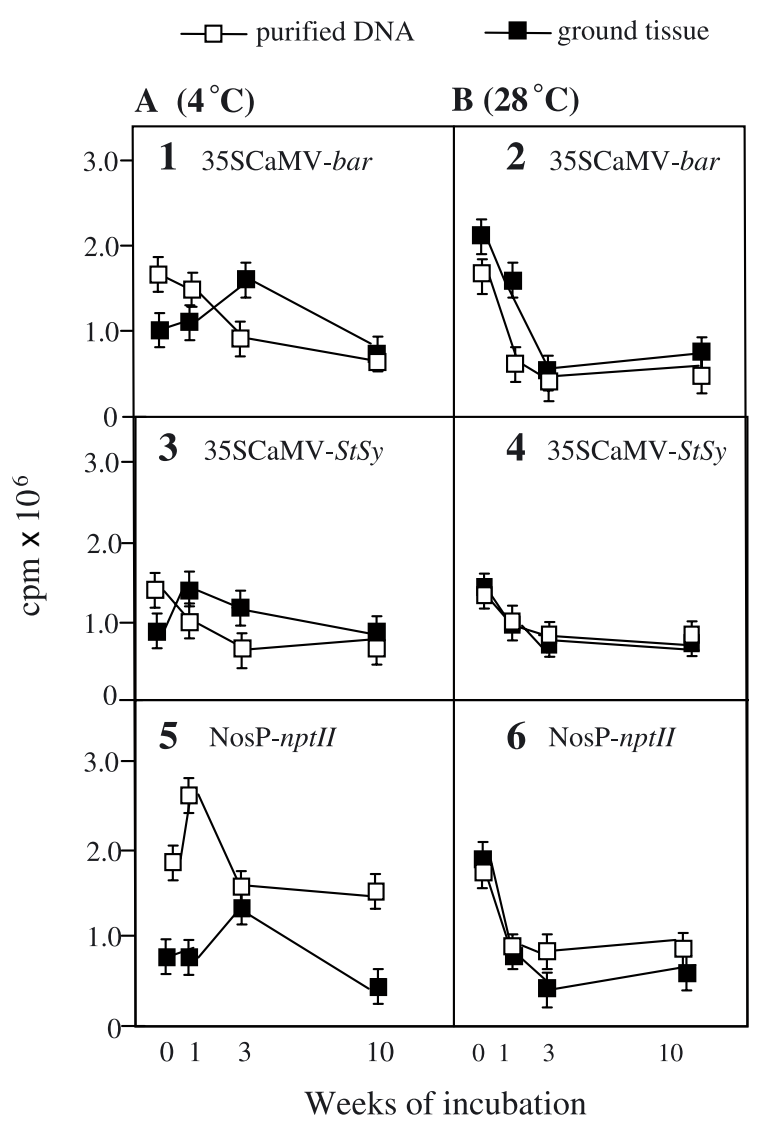

Figure 2. Detection of recombinant DNA sequences in soil microcosms containing purified DNA $(\square)$ and ground leaf tissues ( $\square$ ) from transgenic white poplars. PCR assays were carried out using gene-specific oligonucleotides and the resulting amplification products were hybridized with gene-specific probes. The intensity of hybrization signals, expressed as counts per minute (cpm) is shown. A. Microcosms were incubated at $4{ }^{\circ} \mathrm{C}$ for $0,1,3$ and 10 weeks. B. Microcosms were incubated at $28^{\circ} \mathrm{C}$ for $0,1,3$ and 10 weeks.

pot might explain the higher frequency of positive PCR assays obtained for the pooled samples. The dynamics of spread of recombinant DNA by roots during potato plant growth has been analyzed by de Vries et al. (2003), who carried out both field plot and greenhouse experiments. These authors detected the recombinant nptII sequence in soil collected from non-transformed potato plants grown in close proximity of GM plants. This was due to the presence of roots from transgenic plants that spread rapidly, reaching the neighboring plants. De Vries et al. (2003) remarked that roots can release DNA in soil during plant growth, either as a free molecule or within plant tissue material, due to the in situ destruction of rhizodermis or root cap cells. The finding that also those pools derived from soil cultivated with untransformed plants contained recombinant DNA might be due to contamination occurring during DNA extraction and purification, although spread of GM material caused by the accidental detachment of GM leaves in the greenhouse could not be excluded. Other biological processes, such as those involving microbial nuclease activities, might have affected the integrity of recombinant DNA in the loamy sand. Although in previous work (Balestrazzi et al., 2007), fluctuations were observed in the size of the culturable bacterial fraction able to secrete nucleases and inhabiting the soil of the bar trial, the complex interactions between the soil particles and nucleic acids (Blum et al., 1997) need to be considered.

It is worth noting that discrepancies were observed in the response of soil pools obtained from the poplar trials, since some of them were unexpectedly negative. The non-homogeneous distribution of humic acid and other inhibitors in the soil DNAs might represent a possible explanation for this negative result, since it has been reported that oligonucleotides designed to detect different DNA regions might have different behavior when added to DNA samples with impurities (Krsek and Wellington, 1999).

The presence of 35SCaMV-bar, 35SCaMV-StSy and NosP-nptII sequences was also evaluated in microcosms in the attempt to define the effects of soil temperature and DNA purity on transgene persistence. It is expected that at increasing temperatures the soil microbial activity and particularly the nuclease activity are enhanced, thus affecting the integrity of free DNA (Luo et al., 2001). Experiments were designed according to Widmer et al. (1997), who performed a microcosm study with purified plasmid DNA added to soil and also tested a mixture of soil and ground fresh leaf tissue from transgenic tobacco plants. In the present work, persistence of recombinant DNA in soil microcosms was monitored for approximately three months and the target sequences were always detected. In a different report, Gebhard and Smalla (1999) monitored the persistence of DNA extracted from transgenic sugar beet plants and added to soil microcosms. The purified DNA was mixed with soil and incubated at $20{ }^{\circ} \mathrm{C}$ for different time periods. PCR detection of the nptII and bar genes and their associated promoter regions resulted in the presence of positive signals up to six months after the beginning of the microcosm experiment. They also found that the intensity of the hybridization signal decreased during the first day and subsequently increased. According to these authors, different parts of the constructs may be differently accessible, due to the secondary structures or interactions with the plant genome. In our hands, all the hybridization signals produced by soil microcosms incubated at $28{ }^{\circ} \mathrm{C}$ and two out of the six hybridization bands obtained at $4{ }^{\circ} \mathrm{C}$ decreased one week after the beginning of the experiment, 
and the intensity of signals further decreased during the subsequent time point (three weeks after the beginning of the experiment). Due to the different time period investigated, it is difficult to compare our data with those from sugar beet microcosms.

The semi-quantitative approach used with the recombinant DNA sequences in white poplar microcosms revealed only a partial correlation between the intensity of hybridization signals and the tested parameters (DNA purity and soil temperature). In recent work, Lerat et al. (2005) reported on the quantification of recombinant DNA from GM corn and soybean in soil samples by realtime PCR, and remarked the difficulties in performing amplification due to the presence of co-extracted humic acids. This might represent a possible explanation for the data obtained with our soil microcosms. However, it is worth noting that spectrophotometric analyses carried out to assess the degree of humic acid and protein contamination revealed low levels of these substances (Balestrazzi et al., unpublished results).

\section{MATERIALS AND METHODS}

\section{Soil description}

The agricultural soil used in this study was collected from cultivated fields surrounding the town of Lodi, in the southern part of Lombardy. The soil was mixed with white peat (20\%; Tecnic, Free Peat B. V., The Netherlands) in order to facilitate the rooting of the poplar plantlets. The resulting substrate was classified as a medium-textured loamy sand $(77.43 \%$ sand, $16.93 \%$ silt and $5.62 \%$ clay; $24.58 \%$ organic matter; $62.0 \%$ Water Holding, Cation Exchange Capacity of 3.32 meq. ${ }^{-1}$ with $\mathrm{pH}$ 6.85). The organic $\mathrm{C}$ content and the total $\mathrm{N}$ content were estimated $3.02 \%$ and $0.256 \%$, respectively, which corresponded to a C:N ratio of 11.79 .

\section{Plant materials}

The plant materials, produced by in vitro micropropagation, was transferred into pots and then acclimatized for four weeks in a growth room at $22{ }^{\circ} \mathrm{C}$ under a photoperiod of $16 \mathrm{~h}$, a photon flux density of $150 \mu \mathrm{mol} \cdot \mathrm{m}^{-2} \cdot \mathrm{s}^{-1}$ and a relative humidity of approximately $70-80 \%$. After this period, all the rooted plantlets were transplanted into pots ( $30 \mathrm{~cm}$ diameter, $34 \mathrm{~cm}$ height) containing fresh soil and placed in the greenhouse under equal light intensity and temperature. Plants were supplied with a nutrient solution containing $\mathrm{N}\left(168 \mathrm{mg} . \mathrm{L}^{-1}\right), \mathrm{P}\left(46.5 \mathrm{mg} . \mathrm{L}^{-1}\right)$, K (237.7 mg. $\left.\mathrm{L}^{-1}\right)$, Na (230 mg. $\left.\mathrm{L}^{-1}\right), \mathrm{Ca}\left(200 \mathrm{mg} . \mathrm{L}^{-1}\right)$, Mg (24.3 mg. $\left.\mathrm{L}^{-1}\right), \mathrm{S}\left(81.7 \mathrm{mg} . \mathrm{L}^{-1}\right), \mathrm{Fe}\left(14 \mathrm{mg} . \mathrm{L}^{-1}\right)$, Mn (1.7 mg.. $\left.{ }^{-1}\right)$, B (2.1 mg.. $\left.\mathrm{L}^{-1}\right)$, Zn (1.4 mg.. $\left.{ }^{-1}\right)$, $\mathrm{Cu}\left(0.18 \mathrm{mg} . \mathrm{L}^{-1}\right)$, E.C. $=1.9 \mathrm{mS} . \mathrm{cm}^{-1}, \mathrm{pH}$ 6.0.

\section{Experimental design}

The bar trial consisted of 54 poplars (18 plants for each line) while the $S t S y$ trial was established with 180 poplars (60 plants for each line) (Figs. 1A and 1C). For the analyses carried out on the greenhouse trials, soil samples were collected at a depth of $0-18 \mathrm{~cm}$ from each pot, using a Soil Auger Bucket (Soilmoisture Equipment Corp.). The diameter of the auger was $3 \mathrm{~cm}$. Samples were then transferred to sterile Magenta boxes $(77 \mathrm{~mm} \times 77 \mathrm{~mm} \times$ $97 \mathrm{~mm}$, Sigma Aldrich), maintained at $4{ }^{\circ} \mathrm{C}$, immediately transported to the laboratory and used less than $2 \mathrm{~h}$ after removal. In the bar trial, samples from six different pots were mixed in order to obtain nine composite samples (pools). In the StSy trial, twelve composite pools were obtained. According to this sampling scheme, described in Figures 1B and 1D, each pool contained soil collected from six pots cultivated with the same poplar line. Two independent replicates (composite soil samples) per treatment and sampling point were collected.

\section{Collection of leaf tissues and DNA extraction}

For microcosm experiments, leaves were collected from six-month-old poplar plants during the vegetative growth phase, and immediately frozen in liquid nitrogen. Genomic DNA was extracted from the ground leaves as described by Rogers and Bendich (1988), and concentration evaluated by UV spectrophotometry and agarose gel electrophoresis (Sambrook et al., 1989).

\section{Microcosm design}

Soil aliquots $(2 \mathrm{~g})$ were transferred to $50-\mathrm{mL}$ sterile tubes and intensively mixed with equal amounts of purified genomic poplar DNA extracted from the 5P56 and 12EAC1 lines, respectively (250 ng for each GM line). Thus, $4.46 \times 10^{5}$ poplar genomes were present in a single tube. This corresponded to $4.46 \times 10^{5}$ copies of the $n p t I I$ marker gene and $2.23 \times 10^{5}$ copies of the bar and StSy transgene, respectively. The same experiment was performed by adding $0.5 \mathrm{~g}$ (fresh weight; $0.25 \mathrm{~g}$ from each GM line) of ground poplar leaf tissue to single tubes containing $2 \mathrm{~g}$ of soil. Sterile distilled water was added to the soil to reach a final moisture content of $40 \%$ (v/wt). The microcosms were incubated at $4{ }^{\circ} \mathrm{C}$ and $28{ }^{\circ} \mathrm{C}$, respectively. Two independent experiments were carried out, and for each treatment three different tubes were used as replicates.

\section{Soil DNA extraction and purification}

DNA extraction from soil samples was carried out using the high-salt, SDS-based, extended-heating method 
of Zhou et al. (1996). Crude DNAs were subsequently purified using the GFX ${ }^{\mathrm{TM}}$ PCR DNA and Gel Band Purification kit (Amersham Biosciences) as follows: each crude DNA sample (12.5-25 $\mu \mathrm{L})$ was loaded onto the column, the adsorbed DNA was washed and collected according to the protocol supplied. This step was then repeated and finally the purified DNA was collected and stored at $-20{ }^{\circ} \mathrm{C}$. DNA concentration was evaluated by agarose gel electrophoresis (Sambrook et al., 1989).

\section{PCR analyses}

All PCR reactions were carried out in a final volume of $30 \mu \mathrm{L}$ containing $0.2 \mathrm{mM}$ premixed deoxynucleoside triphosphates (M-Medical S.r.l.), $1.5 \mathrm{mM} \mathrm{MgCl}_{2}$ and 2.5 U Taq DNA Polymerase (DyNAzyme II, Finnzymes, Celbio), using a T Gradient apparatus (Biometra). In order to detect the presence of the recombinant DNA sequences, PCR analyses were carried out using three different oligonucleotide sets (Tab. 1). Three independent PCR assays were carried out, and for each DNA sample three replicas were used. Amplification was carried out as previously described at $94{ }^{\circ} \mathrm{C}$ for $50 \mathrm{~s}, 62^{\circ} \mathrm{C}$ for $50 \mathrm{~s}$, $72^{\circ} \mathrm{C}$ for $2 \mathrm{~min}$ ( 35 cycles). PCR products were separated on $0.8 \%(\mathrm{w} / \mathrm{v})$ agarose gels (Duchefa Biochemicals) and then blotted to membranes (Hybond ${ }^{\mathrm{TM}}-\mathrm{N}^{+}$, Amersham Biosciences) according to the supplier's suggestions.

\section{Molecular probes and Southern blot hybridisation}

The gene-specific probes, containing the nptII, bar and StSy coding regions were obtained by PCR as previously described, using the gene-specific primer sets shown in Table 1. Amplification was carried out at the following conditions: $94{ }^{\circ} \mathrm{C}$ for $1 \mathrm{~min}, 60^{\circ} \mathrm{C}$ for $1 \mathrm{~min}, 72{ }^{\circ} \mathrm{C}$ for $1 \mathrm{~min}$ ( 35 cycles) for the $n p t I I$ sequence, $94^{\circ} \mathrm{C}$ for $50 \mathrm{~s}$, $62{ }^{\circ} \mathrm{C}$ for $50 \mathrm{~s}, 72{ }^{\circ} \mathrm{C}$ for $50 \mathrm{~s}$ ( 35 cycles) for the bar gene, $94{ }^{\circ} \mathrm{C}$ for $50 \mathrm{~s}, 62{ }^{\circ} \mathrm{C}$ for $50 \mathrm{~s}, 72^{\circ} \mathrm{C}$ for $1 \mathrm{~min}$ and $30 \mathrm{~s}$ (35 cycles) for the $S t S y$ gene. PCR products were separated on $0.8-2.0 \%(\mathrm{w} / \mathrm{v})$ agarose gels (Duchefa Biochemicals) and purified from agarose gels using the GFX ${ }^{\mathrm{TM}}$ PCR DNA and Gel Band Purification kit (Amersham Biosciences). Sequence analysis was performed using an ABI 3730XL apparatus (Applied Biosystems). Each gene-specific probe was labeled with $\alpha-\left[{ }^{32} \mathrm{P}\right]$-dCTP using the Hexa Label Plus ${ }^{\mathrm{TM}}$ DNA labeling kit (M-Medical S.r.l.). Filters were hybridized under the following conditions: $50 \%(\mathrm{v} / \mathrm{v})$ formamide, 5 X SSC $(150 \mathrm{mM} \mathrm{NaCl}$, $15 \mathrm{mM} \mathrm{Na} 3$ citrate pH 7.6), 0.5\% SDS, 5 X Denhardt's solution $(0.1 \%$ Ficoll, $0.1 \%$ polyvinylpyrrolidone, $0.1 \%$ bovine serum albumin), $100 \mu \mathrm{g} \cdot \mathrm{mL}^{-1}$ salmon sperm DNA at $42{ }^{\circ} \mathrm{C}$ for $16 \mathrm{~h}$. Final washes were performed under high stringency $\left(0.1 \times \mathrm{XSC} / 0.1 \% \mathrm{SDS}\right.$, at $65^{\circ} \mathrm{C}$ for $10 \mathrm{~min})$. Densitometric analysis was performed using a Biostep $\mathrm{GmbH}$ apparatus with the argus X1 3.3.0 software.

\section{Statistical analyses}

Statistical analysis was carried out using the Microsoft ${ }^{\circledR}$ EXCEL2000 (9.0.2812) statistical package calculating mean and standard error. Results were subjected to Analysis of Variance (ANOVA) and the means compared by the Duncan's Multiple Range Test (MSTAT-C; Crop and Soil Science Department, Michigan State University).

\section{ACKNOWLEDGEMENTS}

This research was supported by a grant from Regione Lombardia (Divisione Generale Agricoltura). M.B. received a doctoral fellowship from Regione Lombardia. We would like to thank Massimo Confalonieri for assistance with statistical analyses.

Received January 11, 2008; accepted April 14, 2009.

\section{REFERENCES}

Alhamd L, Arakaki S, Hagihara A (2004) Decomposition of leaf litter of four tree species in a subtropical evergreen broadleaved forest, Okinawa Island, Japan. For. Ecol. Man. 202: $1-11$

Balestrazzi A, Allegro G, Confalonieri M (2006) Genetically modified trees expressing genes for insect pest resistance. In Fladung M, Ewald D, eds, Tree Transgenesis: Recent Developments, Springer-Verlag, Berlin, Heidelberg, pp 253-273

Balestrazzi A, Bonadei M, Carbonera D (2007) Nucleaseproducing bacteria in soil cultivated with herbicide resistant transgenic white poplars. Ann. Microbiol. 57: 531-536

Blum SAE, Lorenz MG, Wackernagel W (1997) Mechanism of retarded DNA degradation and prokaryotic origin of DNases in non sterile soils. System. Appl. Microbiol. 20: 513-521

Ceccherini MT, Poté J, Kay E, Van V, Marechal J, Pietramellara G, Nannipieri P, Vogel TM, Simonet $\mathbf{P}$ (2003) Degradation and transformability of DNA from transgenic leaves. Appl. Environ. Microbiol. 69: 673-678

Chander K, Goyal S, Kapoor KK (1995) Microbial biomass dynamics during the decomposition of leaf litter of poplar and eucalyptus in a sandy loam. Biol. Fertil. Soils 19: 269-279

Confalonieri M, Belenghi B, Balestrazzi A, Negri S, Facciotto G, Schenone G, DelleDonne M (2000) Transformation of elite white poplar $(P . a l b a) \mathrm{cv}$ 'Villafranca' and evaluation of herbicide resistance. Plant Cell Rep. 19: 978-982 
Cotrufo MF, De Angelis P, Polle A (2005) Leaf litter production and decomposition in a poplar short-rotation coppice exposed to free air $\mathrm{CO}_{2}$ enrichment (POPFACE). Global Change Biol. 11: 971-982

de Vries J, Heine M, Harms K, Wackernagel W (2003) Spread of recombinant DNA by roots and pollen of transgenic potato plants, identified by highly specific biomonitoring using natural transformation of an Acinetobacter sp. Appl. Environ. Microbiol. 69: 4455-4462

England LS, Vincent ML, Trevors JT, Holmes SB (2004) Extraction, detection and persistence of extracellular DNA in forest litter microcosms. Mol. Cell. Probes 18: 313-319

Gebhard F, Smalla K (1999) Monitoring field releases of genetically modified sugar beets for persistence of transgenic plant DNA and horizontal gene transfer. FEMS Microbiol. Ecol. 28: 261-272

Giorcelli A, Sparvoli F, Mattivi F, Balestrazzi A, Tava A, Vrhovsek U, Bollini R, Confalonieri M (2004) Expression of stilbene synthase (StSy) gene from grapevine in transgenic white poplar results in high accumulation of the antioxidant compounds resveratrol glucosides. Trans. Res. 13: 203-214

Hay I, Morency M-J, Seguin A (2002) Assessing the persistence of DNA in decomposing leaves of genetically modified poplar trees. Can. J. For. Res. 32: 977-982

Hobbie SE, Reich PB, Oleksyn J, Ogdahl M, Zytkowiak R, Hale C, Karolewski P (2006) Tree species effects on decomposition and forest floor dynamics in a common garden. Ecology 87: 2288-2297

Keese P (2008) Risks from GMOs due to Horizontal Gene Transfer. Environ. Biosafety Res. 7: 123-149

Krsek M, Wellington EMH (1999) Comparison of different methods for the isolation and purification of total community DNA from soil. J. Microbiol. Methods 39: 1-16

Lerat S, England LS, Vincent ML, Pauls KP, Swanton CJ, Klironomos JN, Trevors JT (2005) Real-time polymerase chain reaction quantification of the transgenes for Roundup Ready corn and Roundup Ready soybean in soil samples. J. Agric. Food Chem. 53: 1337-1342

Lilley AK, Bailey MJ, Barr M, Kilshaw K, Timms-Wilson TM, Day MJ, Norris SJ, Jones TH, Godfray HCJ (2003) Population dynamics and gene transfer in genetically modified bacteria in a model microcosm. Mol. Ecol. 12: 30973107

Luo Y, Wan S, Hui D, Wallace LL (2001) Acclimatization of soil respiration to warming in a tall grass praire. Nature 413: $622-625$
Monier J-M, Bernillon D, Kay E, Faugier A, Rybalka O, Dessaux Y, Simonet P, Vogel TM (2007) Detection of potential transgenic plant DNA recipients among soil bacteria. Environ. Biosafety Res. 6: 71-83

Pontiroli A, Simonet P, Frostegard A, Vogel TM, Monier J-M (2007) Fate of transgenic plant DNA in the environment. Environ. Biosafety Res. 6: 15-35

Richter B, Smalla K (2007) Screening of rhizosphere and soil bacteria for transformability. Environ. Biosafety Res. 6: 91-99

Rogers SO, Bendich AJ (1988) Extraction of DNA from plant tissues, Gelvin SB, Schilperoort RA, eds, Plant Molecular Biology Manual, Kluwer, Dordrecht, pp A6, 1-10

Sambrook J, Fritsch EF, Maniatis T (1989) Molecular Cloning: A Laboratory Manual, 2nd edn, Cold Spring Harbor Laboratory, Cold Spring Harbor, NY

Sparvoli F, Martin C, Scienza A, Gavazzi G, Tonelli C (1994) Cloning and molecular analysis of structural genes involved in flavonoid and stilbene biosynthesis in grape (Vitis vinifera L.). Plant Mol. Biol. 24: 743-755

Thompson CJ, Movva NR, Tizard R, Crameri R, Davies JE, Lawereyes M, Botterman J (1987) Characterization of the herbicide-resistance gene bar from Streptomyces hygroscopicus. EMBO J. 6: 2519-2523

Van Overbeek L, Ray J, Van Elsas JD (2007) Assessment of transformability of bacteria associated with tomato and potato plants. Environ. Biosafety Res. 6: 85-89

Widmer F, Seidler RJ, Donegan KK, Reed GL (1997) Quantification of transgenic plant marker gene persistence in the field. Mol. Ecol. 6: 1-7

Zelasco S, Reggi S, Calligari P, Balestrazzi A, Bongiorni C, Quattrini E, Delia G, Bisoffi S, Fogher C, Confalonieri M (2006) Expression of the Vitreoscilla hemoglobin (VHb)-encoding gene in transgenic white poplar: plant growth and biomass production, biochemical characterization and cell survival under submergence, oxidative and nitrosative stress conditions. Mol. Breed. 17: 201-216

Zelasco S, Ressegotti V, Confalonieri M, Carbonera D, Calligari P, Bonadei M, Bisoffi S, Yamada K, Balestrazzi A (2007) Evaluation of MAT-vector system in white poplar (Populus alba L.) and production of ipt marker-free transgenic plants by 'singlestep transformation'. Plant Cell Tiss. Organ. Cult. 91: 61-72

Zhou JZ, Bruns MA, Tiedje JM (1996) DNA recovery from soils of diverse composition. Appl. Environ. Microbiol. 62: 316-322 